\title{
SOCIO-ECONOMIC DETERMINANTS OF WATER LEAF PRODUCTION IN CALABAR MUNICIPALITY AND CALABAR SOUTH LOCAL GOVERNMENT AREAS OF CROSS RIVER STATE
}

I. C. IDIONG, E. E. EKPE, A. I. CHARLES and E. J. UDOH

(Received 25 May 2001; Revision accepted 9 January 2002)

\section{ABSTRACT}

The study was carried out to determine the socio-economic variables that affect the output of waterleaf in Calabar Municipality and Calabar South Local Government Areas of Cross River State.

Data for the investigation were collected from 30 farmers (15 in each location) selected for the study through personal interviews and participatory observation. Frequency tables were used in data presentation while an analysis involving the use of Ordinary Least Square (OLS) multiple regression technique was carried out. The log-linear functional form was selected as the lead equation and used for discussion. The study revealed that the respondents were mostly females with farm sizes ranging from $50-100 \mathrm{~m}^{2}$.

The coefficients of fertilizer $\left(X_{1}\right)$, farming experience $\left(X_{2}\right)$ and frequency of cutting $\left(X_{3}\right)$ carried positive signs and were significant at the one per cent level. The elasticities of production with respect to these three variables were $1.03,0.803$ and 0.151 respectively. The independent variables operating jointly explained about 94 per cent of the variation in output of waterleaf in the area. The implication of the findings is that the presence of increasing returns to scale is an indication of existence of the potentials for increased production vis-à-vis income by women farmers in the area.

Keywords: Socio-economic, water leaf, determinants, production

\section{INTRODUCTION}

Waterleaf (Talinum triangulare) a vegetable that is widely cultivated in the southern part of Nigeria and particularly in Cross River and Akwa Ibom States is known to be a good substitute for meat as a source of protein. Its short production period and high digestibility as well as the ease of its cultivation as a result of its low economic and capital requirements are the reasons adduced for its cultivation, (Epenhuijsen, 1974 and Ojomo, 1976).

Maduka (1998) reported that, waterleaf production is a major source of income of women farmers in Calabar Municipality. Its high demand is attributed to its importance as a "softener" when cooking fibrous vegetables such as Afang (Gnetum africanun), Atama (Heinsia crinata), and fluted pumpkin (Telferia occidentalis). Its usefulness is evidenced much more in the preparation of the favourite and popular soups of the Efiks, "Ukwoho afang" and "Edikang ikong". Waterleaf is cultivated either from stem cuttings or seeds. It grows to a height of $30-60 \mathrm{~cm}$ before harvest. Rice et al (1986) reported that, under proper cultural management, the vegetable is due for harvest from 35 - 45 days after planting. To induce the development of laterals, terminals are normally removed early.

Several factors influence the output of any crop including vegetables. Umoh (1998) and Okezie (1995) reported that output of telfeiria is positively influenced by the size of the farm it is cultivated. Umoh (1998) also reported that the frequency of cutting significantly and positively influences the output of the vegetable. Other factors that have effect on output of vegetables include fertilizer use, level of education of the farmer, farm size etc; (Okezie, 1995; Udoh, 1994, John, 1997).

Waterleaf production in Calabar has been
I. C. IDIONG, Department of Agricultural Economics and Extension, University of Calabar, Calabar, Nigeria.
E. E. EKPE, Department of Agricultural Economics and Extension, Universiy of Calabar, Calabar, Nigeria
A. I. CHARLES, Department of Agricultural Economics and Extension, University of Calabar, Calabar, Nigeria.
E. J. UDOH, Department of Agricultural Economics and Extension, Universiy of Uyo, Uyo, Nigeria 
reported to be quite profitable and most studies carried out on waterleaf production have focussed on cost and returns, (Udoh, 1994 and Maduka, 1998). Very few studies have considered social factors such as years of farming experience and some cultural practices such as frequency of cutting as having effect on output of waterleaf, especially in the Caldibar Municipality and Calabar South Local Government Areas of Cross River State in spite of the increasing importance of this vegetable in the area.

The study was therefore carried out to ascertain some socio-economic determinants of waterleaf production in the two Local Government Areas of the State. It will specifically determine:

i. The socio-economic characteristics of the farmers;

ii. The effect of frequency of cutting, years of farming experience and fertilizer application on the output of waterleaf in the areas.

\section{METHODOLOGY}

\section{Study Area, Data Collection and Sampling Procedure}

The study was carried out in Calabar city of Cross River State, which presently consist of two Local Government Areas namely Calabar South and Calabar Municipality. It has a total landmass of $1480 \mathrm{sq} \mathrm{km}$ with estimated population of 320,862 of which 166,203 and 154,659 are males and females respectively (1991 Census, Udoh, 1999). The occupations of the residents reflect the economic characteristics of the area. With its status as an administrative capital, many government workers reside here. Some commercial activities are also

practised. However, to complement sources of family income, many individuals are involved in farming activities within and around the city. These primarily centre on the production of $\because$ bles in home gardens in which waterleaf culuvation features prominently (Udoh, 1999).

Data used in the study were primary data collected directly from the farmers with the use of interview schedules and also through participatory observations during the months of September through November 2000. A total of
30 farmers were randomly sampled from two locations - Uwanse and lkot Ansa districts. These locations were chosen for the study because of intensity of production and the near absence of any previous studies.

\section{Analytical Procedure:}

The study utilised both econometric and descriptive methods of analysis to fulfil the stated objectives. Primarily, descriptive statistics was used to the analyse socioeconomic characteristics of the farmers.

\section{Model Specification:}

Specification of model was necessary to quantitatively estimate a typical production function for waterleaf in the municipality. Accordingly, the study assumes a classical production function that is twice differentiable and increasing within its domain. The model is specified as:

$$
Y=f(X, \beta)+e ;(i=1,2 \text { and } 3)
$$

Where $Y=$ output of waterleal per squarc meter $\left(\mathrm{kg} / \mathrm{m}^{2}\right)$

$$
\begin{aligned}
& X_{i}=\text { vector of variable inputs } \\
& \beta=\text { vector of parameters to be estimated } \\
& e=\text { error term. }
\end{aligned}
$$

The study considers two functional forms linear, and double log-functions. This is because these models are regular and strictly quasiconcave functions over their domain. Within the confine of necessary assumptions, Ordinary Least Square (OLS) method was used in the estimation of the parameters, I's due to its optimal adaptability for studies of this magnitude. A priori reasoning requires that $\mathrm{D}^{\prime} \mathrm{s}$ $>0$. However, on a more specific way, the inputs included in the model are fertilizer applied in $\mathrm{kg}$, numbers of years of farming and frequency of cutting.

To implicitly assume a linear production function and a double-log function la Cobb-Douglas production function) is based on their wider application in estimating agricultural production functions of this nature (Udoh, 1999). Specifically, the Cobb-Douglas production function mostly gives parsimonious parameters that require no complex computation and can be 
Table 1: Distribution of Respondents Based on Selected Socio-economic characteristics.

\begin{tabular}{lllll}
\hline Variables & $\begin{array}{l}\text { Calabar South } \\
\text { Frequency }\end{array}$ & $\%$ & $\begin{array}{c}\text { Calabar Municipality } \\
\text { Frequency }\end{array}$ & $\%$ \\
\hline $\begin{array}{l}\text { Male } \\
\text { Female }\end{array}$ & - & - & - & - \\
\hline Total & 15 & 100 & 15 & 100 \\
\hline
\end{tabular}

Farming Experience (Years)

\begin{tabular}{lllll}
$1-5$ & 6 & 40 & 5 & 33.33 \\
$6-10$ & 5 & 33.33 & 6 & 40.00 \\
$11-15$ & 3 & 20.00 & 2 & 13.33 \\
$>15$ & 1 & 6.67 & 2 & 13.33 \\
\hline Total & 15 & 100 & 15 & 100.00 \\
\hline
\end{tabular}

Educational Level

No education

Primary education 5

33.33

2

13.33

Secondary Education 9

60.00

13

86.67

Tertiary education 1

6.67

\begin{tabular}{lllll}
\hline Total & 15 & 100 & 15 & 100.00 \\
\hline Farm Size $\left(\mathrm{m}^{2}\right)$ & & & & \\
$50-100$ & 8 & 53.33 & 10 & 66.67 \\
$101-150$ & 6 & 40.00 & 2 & 13.67 \\
$>150$ & 1 & 6.67 & - & - \\
\hline Total & 15 & 100 & 15 & 100.00 \\
\hline
\end{tabular}

Source: Field Survey, 2000.

easily interpreted (Heady and Dillon 1969; Learner 1983; Hussain and Young, 1985).

\section{Results and Discussion:}

Socio-economic Characteristics of Respondents.

\section{Sex:}

Table 1 indicates that, waterieaf producers in the areas were all female. This confirms similar findings by Maduka (1998), that waterleaf is a major source of income of women farmers in Calabar Municipality.

\section{Farming Experience:}

About 73.3 per cent of the respondents have between one and ten year's experience in waterleaf production. In fact the median farming experience of $6-10$ years alone constituted about 53.3 per cent of the total population of waterleaf growers. This would therefore imply that, majority of the respondents have been in the business for long and were therefore conversant with the problems in the area.

However only 26.67 per cent had been growing the vegetable for upward of 11 years and above.

\section{Educational Level:}

Table 1 also indicates that, $33.33 \%$ and 60 per cent of the respondents in Calabar South attained the primary and secondary school levels of education respectively, while $13.33 \%$ and $86.67 \%$ had equivalent levels of education respectively in Calabar Municipality. These results imply that, the majority of the respondents were literate and this would therefore augur well for extension services with 
special reference to urban vegetable production.

\section{Farm Size:}

Table 1 further indicates that the farm size cultivated by majority of the waterleat growers $153.3 \%$ in Calabar South and $66.67 \%$ in Calabar Municipality) were quite small $\left(50-100 \mathrm{~m}^{2}\right)$. This is an indication of the small-scale nature of waterleaf production in the area.

\section{Effect of Frequency of Cutting, Farming Experience and Fertilizer Application on Output of Waterleaf:}

Two production functions were estimated. These were the linear and log linear functions. These functional forms were selected "a priori". The estimates are presented in equations 1 and 2 below: $\mathrm{Y}=-3.871+231,896 \mathrm{X}_{1}{ }^{*}+9.136 \mathrm{X}_{2}{ }^{*}+0.101 \mathrm{X}_{3}{ }^{*} \ldots$. (1)

$$
\begin{array}{llll}
(0.428) & (22.274) \quad(6.028) & (0.027)
\end{array}
$$$$
R^{2}=0.95, \quad R^{2}=0.94, \quad \text { Fratio }=162.048
$$

$\ln Y=2.742+1.031 \ln X_{1}{ }^{*}+0.803 \ln X_{2}{ }^{*}+0.151 \ln X_{3}{ }^{*}$

$$
\begin{array}{ccc}
(0.841) \quad(0.118) & (0.143) \quad(0.039) \\
R^{2}=0.95, & R^{2}=0.94, \quad \text { F-ratio }=142.668
\end{array}
$$

Note: Standard errors in parentheses.

*t-value - significant at 1 per cent level.

The log linear functional form (Eq.2) was chosen as the lead equation not just because of the appropriateness of the signs of the coefficients but also the ease of estimation of elasticities of production with respect to the variables as well as interpretation of the results as indicated in the

Table 2:

\section{Estimate of Elasticities of Production (EP)}

\begin{tabular}{lc}
\hline Variables & EP \\
\hline Fertilizer & 1.030 \\
Frequency of cutting & 0.803 \\
Farming experience & 0.151 \\
\hline Total & 1.984
\end{tabular}

analytical procedure. The coefficients of fertilizer applied $\left(X_{1}\right)$, farming experience $\left(X_{2}\right)$ and frequency of cutting $\left(X_{3}\right)$ were $1.03,0.803$ and 0.151 respectively (Eq.2) and were significant at the one per cent level. This implies that an increase (decrease) in these variables will significantly lead to an increase (decrease) in

output per square meter of waterleaf in the area. The coefficient of determination $\left(R^{2}=0.94\right)$ indicated that 94 percent of the variability in output of waterleaf is explained by the three variables. The F-ratio (Fcal $=142.668$ ) showed the overall significance of the equation at the 1 per cent level. The results confirm similar findings by Okezie (1995), John (1997) and Umoh (1998).

The elasticities of production with respect to three variables were $1.03,0.803$ and 0.151 respectively (Table 2 ). The results show that a $10 \%$ increase in fertilizer applied will lead to 10.3 per cent increase in output of waterleaf and vice versa. It also shows that a $10 \%$ increase in farming experience and frequency of cuttings respectively will lead to 8.03 and 1.51 per cent increase in output of waterleaf and vice versa. The sum of the elasticities was 1,984. This result indicates that the farmers were experiencing increasing marginal returns and that there were operating in the first stage of the production function. There is therefore the need for the farmers to increase production beyond this stage. Maduka 11998) obtained similar results.

\section{IMPLICATIONS OF THE MAJOR FINDINGS:}

The results of the study indicated the presence of increasing returns to scale. Consequently it can be concluded that the farmers need to expand their production in order to gain production input efficiencies. In fact, since it was found out that waterleaf is predominantly a women's crop, there is need for government to focus greater attention on the production of this crop if its poverty eradication programmes are to be effective. Adoption of this crop in the programme is capable of enhancing the incomes of the women farmers in the area. 


\section{REFERENCES}

Epenhujiser, C. W., 1974. Growing Native Vegetables in Nigeria. F A O Rome.

Heady, E. O. and Dillion, J. L., 1969. Agricultural Production Functions. Kalyani Publishers, Ludhians, India.

Hussain, R. Z. and Young, R. A., 1985. "Estimates of the Economic Value of Productivity of irrigation Water in Pakistan from farm Survey". Water Research Bulletin, 21:

John, A. J., 1997. "Socio-economic Analysis of Soybean Production in Gboko, Benue State". Unpublished B. Agric. Dissertation, Department of Agricultural Economics and Extension, University of Calabar, Calabar.

Learner, E. E. 1983. "Let's take the Con out of Econometrics". American Economic Review, $73: 31$ - 43

Maduka, C., 1998. "Economics Production of Waterleaf". Unpublished B. Agric Dissertation, Department of Agric Economics and Extension, University of Calabar.

Ojomo, E. C., 1976. Practical Handbook of Agriculture Chico Press, Zaria.
Okezie, C. A.; 1995."Fconomic Analysis of the Production and Marketing of Waterleaf in Calabar, Cross River State:- Unpublished B. Agric Dissertation, Deparunent of Agricultural Economic Extension, University of Calabar.

Rice, R. P; Rice, 1. W. and Tindall, H. D., 1986. Fruit and Vegetables in the Tropics. Macmillan Educational Books Ltd. London.

Udoh, E. J., 1994. "Economics of Waterleaf Production in Calabar Municipality of Cross River State". Unpublished B. Sc. Dissertation, Department of Agric Economics and Extension, University of Calabar.

Udoh, E. J., 1999. "Commercial Production of Waterleaf among Urban Women". A Case study of Calabar Municipality of Cross River State. In Poverty Alleviation and Food Security in Nigeria. (eds) Fabiyi, Y. L. and Idowu, E. O. Kayod, (Nig) L.td. Ibadan.

Umoh, H., 1998. "Economics of Dry Scason Production of Fluted Pumpkin in Itu Local Government Area, Akwa Ibom State". Unpublished B. Agric Dissertation, Department of Agric Econs/Extension, University of Calabar. 